\title{
Trait Associations in Prostrate and Semi-Leaf Less Type Field Pea (Pisum sativum L.) Gene Pools
}

\author{
Kedir Yimam Assen \\ Kulumsa Agricultural Research Center, Asella, Ethiopia \\ Email address: \\ kediryimam95@gmail.com \\ To cite this article: \\ Kedir Yimam Assen. Trait Associations in Prostrate and Semi-Leaf Less Type Field Pea (Pisum sativum L.) Gene Pools. American Journal of \\ Environmental Science and Engineering. Vol. 4, No. 4, 2020, pp. 54-60. doi: 10.11648/j.ajese.20200404.11
}

Received: June 24, 2020; Accepted: September 16, 2020; Published: November 23, 2020

\begin{abstract}
The field experiment was conducted in 2019 main cropping season at two locations using simple lattice design to evaluate 49 field pea genotypes including nine released varieties for generating information on genotypic and phenotypic association among yield contributing traits and with grain yield, and to study their path analysis on grain yield. Positive and significant genotypic correlation observed between grain yield with plant height ( $\mathrm{rg}=0.67)$, seeds per pod ( $\mathrm{rg}=0.45)$, days to maturity $(\mathrm{rg}=0.41)$ and pods per plant $(\mathrm{rg}=0.33)$ for combined analysis. The association among most of traits demonstrated higher genotypic correlations than corresponding phenotypic correlations that; indicated the prevalence of genetic variation in expression of the traits. Genotypic path analysis also indicated that plant height $(0.746)$ exerted the maximum positive direct effect on grain yield followed by stand count at harvest $(0.443), 1000$ seed weight $(0.372)$, seeds per pod (0.214), pods per plant (0.213), and days to maturity (0.013). Therefore; selection for traits such as plant height, pods per plant, seeds per pod and days to maturity could improve grain yield in field pea.
\end{abstract}

Keywords: Genotypic, Phenotypic, Correlation, Direct Effect, Indirect Effect

\section{Introduction}

Economically, Pulses are the second most important crops after cereals in the world's crop production. Field pea (Pisum sativum L.) is one of the most widely grown pulse crop in the world with annual production of 16205448 tonnes [8]. The major field pea-producing countries include Canada, Russian Federation, China, Ukraine, India, United States of America, France, Australia, Ethiopia and Germany [8].

In Ethiopia, field pea stands fourth next to faba bean, haricot bean and chickpea among pulse crops in total production and areas coverage [6]. It is grown on 220,508.39 hectares of land with total production of $368,519.065$ tonnes and productivity of $1.671 \mathrm{t} / \mathrm{ha}$; which accounts $13.79 \%$ from pulses total area coverage and $12.37 \%$ from total production in Ethiopia. [6]. It is widely cultivated in potential mid and high altitude areas of the country at elevations of 1800-3000 $\mathrm{m}$ with 700-1100 $\mathrm{mm}$ annual rainfall.

Field pea can be grouped in to two main types. The first is prostrate type that has normal leaves (vine lengths of 3 to 6 feet) and the second type is the semi leafless that has modified leaflets (shorter vine lengths of 2 to 4 feet) reduced to tendrils [9].

Field pea has a great economic merit in the livelihood of the agricultural societies of the country. It contains high protein content, favorable amino acids composition and low trypsin inhibitor levels and there by supply the essential nutrients to various age groups [2] Due to its pertinent atmospheric nitrogen fixing capacity; field pea serves as a break crop suitable for rotation in areas where cereal monocropping is abundant.

Even though it has huge importance in the country, the national average production of field pea is low compared with the production of the crop in the advanced countries like India, USA, France [8]. This may be due to inherent low yielding potential of the landrace cultivars, biotic factors (diseases like powdery mildew (Erysiphe polygoni) and Ascochyta blight (Mycosphaerella pinodes)) and abiotic (frost) factors, inadequate land allocation, poor attention for the crop, instability of cultivars, poor adaptation and poor crop management $[20,16]$. To increase the production of this crop there is a need to develop further desirable genotypes.

The improvement of field pea through phenotypic selection by their yield alone is not possible because grain 
yield is a complex quantitative character affected by many environmental factors and genotype by environment interaction [18].

The association of heritable characters with yield attributing traits is useful for selection which can be determines by Correlation analysis [5]. Correlation studies determine the contribution of different characters, type, nature and degree of association among yield related traits and with grain yield [12]. The division of correlation coefficients can be partitioned into direct and indirect effects to give the importance to the casual factors through path coefficient analysis.

Moreover, Even if several research findings indicated the occurrence of strong association between grain yield and yield contributing traits in field pea; limited information is available in association between grain yield and yield contributing traits in Prostrate and Semi-Leaf Less Type Field Pea. Therefore; it is essential to understand the nature and magnitude of association among yield components and with grain yield to select yield related traits indirectly for grain yield improvement. The current study was conducted to estimate the nature and degree of association among yield contributing traits and with grain yield, and to study their path analysis on grain yield.

\section{Materials and Methods}

\subsection{Experimental Materials and Sites}

Forty nine field pea materials including, twenty one introduced field pea materials; nineteen single plants selected from bulked gene pool materials and nine released varieties were evaluated at Bekoje $(2780 \mathrm{~m}$ altitude, $1010 \mathrm{~mm}$ average annual rain fall with $7.9-16.6^{\circ} \mathrm{C}$ temperature) and Kofele (2660m altitude, $1211 \mathrm{~mm}$ average annual rain fall with 7.1 $18^{\circ} \mathrm{C}$ temperature) [19] in south-eastern highlands of Ethiopia during the main season of 2018/19 cropping season.

Table 1. List of field pea genotypes used in the Study.

\begin{tabular}{|c|c|c|c|c|}
\hline No & Genotype & Source & Origin & Plant type \\
\hline 1 & GPHA-05 & HARC & SPS & $\mathrm{P}$ \\
\hline 2 & GPHA-013 & HARC & SPS & $P$ \\
\hline 3 & GPHA-03 & HARC & SPS & $\mathrm{P}$ \\
\hline 4 & GPHA-019 & HARC & SPS & $\mathrm{P}$ \\
\hline 5 & GPHA-02 & HARC & SPS & $\mathrm{P}$ \\
\hline 6 & GPHA-010 & HARC & SPS & $P$ \\
\hline 7 & GPHA-07 & HARC & SPS & $\mathrm{P}$ \\
\hline 8 & GPHA-08 & HARC & SPS & $P$ \\
\hline 9 & GPHA-06 & HARC & SPS & $\mathrm{P}$ \\
\hline 10 & GPHA-012 & HARC & SPS & $P$ \\
\hline 11 & GPHA-04 & HARC & SPS & $P$ \\
\hline 12 & GPHA-016 & HARC & SPS & $\mathrm{P}$ \\
\hline 13 & GPHA-09 & HARC & SPS & $P$ \\
\hline 14 & GPHA-01 & HARC & SPS & $\mathrm{P}$ \\
\hline 15 & GPHA-018 & HARC & SPS & $\mathrm{P}$ \\
\hline 16 & GPHA-017 & HARC & SPS & $\mathrm{P}$ \\
\hline 17 & GPHA-014 & HARC & SPS & $P$ \\
\hline 18 & GPHA-011 & HARC & SPS & $\mathrm{P}$ \\
\hline 19 & GPHA-015 & HARC & SPS & $\mathrm{P}$ \\
\hline 20 & P -313-010 & ICARDA & Australia & S \\
\hline 21 & P -313-045 & ICARDA & Australia & $\mathrm{S}$ \\
\hline 22 & P -313-086 & ICARDA & Australia & $\mathrm{S}$ \\
\hline 23 & P -313-082 & ICARDA & Australia & $\mathrm{S}$ \\
\hline 24 & P -313-042 & ICARDA & Australia & S \\
\hline 25 & P -313-071 & ICARDA & Australia & S \\
\hline 26 & PDFPTBEK & ICARDA & Australia & $\mathrm{S}$ \\
\hline 27 & G227 63-2C & HARC & $\mathrm{G} 22763-2 \mathrm{c}$ & $\mathrm{P}$ \\
\hline 28 & P -313-053 & ICARDA & Australia & S \\
\hline 29 & P $-313-070$ & ICARDA & Australia & S \\
\hline 30 & P -313-027 & ICARDA & Australia & $\mathrm{S}$ \\
\hline 31 & P -313-065 & ICARDA & Australia & S \\
\hline 32 & P $-313-026$ & ICARDA & Australia & S \\
\hline 33 & P -313-090 & ICARDA & Australia & $\mathrm{S}$ \\
\hline 34 & P -313-046 & ICARDA & Australia & $\mathrm{S}$ \\
\hline 35 & MILKEY & HARC & NEP63 X180-1/ Holeta & $\mathrm{P}$ \\
\hline 36 & P-313-098 & ICARDA & Australia & $\mathrm{S}$ \\
\hline 37 & HASABE & HARC & JI No 116 & $\mathrm{P}$ \\
\hline 38 & HOLETA & HARC & Hlocal-90/ holeta & $\mathrm{P}$ \\
\hline 39 & WALMERA & HARC & FpExDz X 305PS2108 & $P$ \\
\hline 40 & p-313-059 & ICARDA & Australia & $\mathrm{S}$ \\
\hline 41 & p-313-061 & ICARDA & Australia & $\mathrm{S}$ \\
\hline 42 & p-313-068 & ICARDA & Australia & $\mathrm{S}$ \\
\hline
\end{tabular}




\begin{tabular}{lllll}
\hline No & Genotype & Source & Origin & Plant type \\
\hline 43 & p-313-089 & ICARDA & Australia & S \\
44 & p-313-067 & ICARDA & Australia & A \\
45 & p-313-003 & ICARDA & G22763-2C X 305PS210813 & P \\
46 & ADI & HARC & EH-92004-02 & P \\
47 & BURKITU & HARC & & P \\
48 & BILALO & KARC & P \\
49 & BURSA & KARC & & \\
\hline
\end{tabular}

Where, SPS=single plant selection from gene pool, KARC=Kulumsa Agricultural Center, HARC=Holeta Agricultural Center, ICARDA=International Center of Agricultural Research for Dry Areas.

$\mathrm{P}=$ Prostrate type, $\mathrm{S}=\mathrm{Semi}$ leaf less type.

\subsection{Experimental Design}

The experiment was laid out in a $7 \times 7$ simple lattice design. Each plot consisted of two rows of $4 \mathrm{~m}$ length with spacing of $20 \mathrm{~cm}$ between rows and $5 \mathrm{~cm}$ between plants. Each genotype was planted in a plot size of $1.6 \mathrm{~m}^{2}$. The space between plots within block was $1 \mathrm{~m}$ and between blocks was $1.5 \mathrm{~m}$. A total of 80 seeds per row were sown and each plot contained total of 160 seeds. $100 \mathrm{Kg} / \mathrm{ha}$ DAP fertilizer was applied during planting. Weeding and all other recommended agronomic practices were followed for both locations. For statistical analysis, yield from net plot area of $1.6 \mathrm{~m}^{2}$ was harvested and converted into $\mathrm{kg} \mathrm{ha}{ }^{1}$ base at $10 \%$ standard grain moisture content.

\subsection{Data Collection and Analysis}

Data on days to $50 \%$ flowering, days to $95 \%$ physiological maturity, 1000 seed weight (g), grain yield ( $\mathrm{kg}$ ha-1), ascochyta blight (1-9), and powdery mildew (1-9) were assessed on plot bases, while plant height $(\mathrm{cm})$, pods plant ${ }^{1}$ and seeds pod- 1 were recorded on five random samples of plants selected from the central rows of each plot. Mean values of the five random samples of plants plot- ${ }^{1}$ were then used for the analysis of data collected on an individual plant basis.

Phenotypic and genotypic correlation coefficients of grain yield with other traits were estimated from combined over the two locations using the components of variance and covariance based on the standard procedure suggested by (Robinson et al., 1951) by using the PROC CANDISC of SAS system [15] as follows:

$$
\begin{aligned}
& \mathrm{rp}=\frac{\operatorname{Cov} p(X Y)}{\sqrt{\operatorname{var}} p X \sqrt{\text { var }} p Y} \\
& \mathrm{rg}=\frac{\operatorname{Cov} g(X Y)}{\sqrt{v a r} g X \sqrt{v a r} g Y}
\end{aligned}
$$

Where rp is phenotypic correlation coefficient between characters $\mathrm{x}$ and $\mathrm{y}$; $\mathrm{rg}$ is genotypic correlation coefficient between characters $\mathrm{x}$ and $\mathrm{y}$; $\operatorname{Cov} \mathrm{p}(\mathrm{XY})$ is phenotypic covariance between characters $\mathrm{x}$ and $\mathrm{y}$; var $\mathrm{pX}$ is variance of character $\mathrm{x}$; var $\mathrm{pY}$ is variance of character $\mathrm{y}$; $\operatorname{Cov} \mathrm{g}(\mathrm{XY})$ is genotypic covariance between characters $\mathrm{x}$ and $\mathrm{y}$; var $\mathrm{gX}$ is genotypic variance of character $\mathrm{x}$; and var $\mathrm{gY}$ is genotypic variance of character $y$.

Based on genotypic and phenotypic correlation, path coefficient which refers to the direct and indirect effects of the yield components (independent characters) on grain yield (dependent character) was found out.

The direct and indirect effects of the independent characters (yield components) on dependent variable (yield) were estimated as described by [7] using the following formula.

$$
\text { rij }=\text { Pij }+ \text { Srikpkj }
$$

where, rij=mutual association between the independent

character (i) and dependent character (j) as measured by the correlation coefficients, Pij=direct effects of the independent character (i) on the dependent variable (j) as measured by the path coefficients, and $\Sigma$ rikpkj=summation of components of indirect effects of a given independent character (i) on a given dependent character (j) via all other independent traits $(\mathrm{k})$.

The residual effect, which determines how best the causal factors account for the variability of the dependent factor, yield, was obtained using the formula [17];

$1=p 2 R+\Sigma$ pijrij, where, $p 2 R$ is the residual effect and Epijrij is summation of the product of direct effect of any variable and its correlation coefficient with yield.

\section{Results and Discussion}

\section{Phenotypic and Genotypic Correlation}

The phenotypic and genotypic correlation among grain yield and yield components are indicated in Table 2.

The Grain yield showed highly significant $(\mathrm{P} \leq 0.01)$ positive genotypic correlation with plant height $(\mathrm{rg}=0.67)$, seeds pod- $1(\mathrm{rg}=0.45)$, days to maturity $(\mathrm{rg}=0.41)$ and significant positive genotypic correlation with pods per plant $(\mathrm{rg}=0.33)$. It indicates the possibility of improving grain yield by improving any one / two or all of the traits.

[4] Reported highly significant positive genotypic correlation of seeds per pod and days to maturity with seed yield per plant supporting this finding. Similar result was also reported by [13] where, significant positive genotypic correlation of pods per plant with seed yield per plant. In contrast to this, this author reported negative significant genotypic correlation of days to maturity, plant height and negative non-significant genotypic correlation of seeds per pod. [3] Reported highly significant and positive genotypic correlation of pods per plant, plant height and seeds per pod with yield in garden pea, supported the present findings. Stand count at harvest, 100 seed weight and powdery mildew 
disease demonstrated non-significant positive genotypic association with grain yield. Days to flowering and ascochyta blight disease showed non- significant negative genotypic association with grain yield.

Days to flowering demonstrated a significant and positive genotypic correlation with days to maturity. It implies that plants that early flower may mature earlier. Days to maturity showed a significant and positive genotypic correlation with number of pods per plant. Days to maturity and plant height showed a significant and positive genotypic correlation with number of seeds per pod. It indicates that tall plants supporting many leaves could increase total biomass production through increased carbon fixation that can be ultimately partitioned to reproduction organ and there by produce more number of seeds and increase seed yield in field pea, which has positive and significant correlation with crop improvement. Similar result was reported by [11].

Grain yield showed highly significant $(\mathrm{P} \leq 0.01)$ positive phenotypic correlation with plant height $(\mathrm{rp}=0.57),(\mathrm{rg}=0.45)$, days to maturity $(\mathrm{rg}=0.33)$ and significant positive phenotypic correlation with pods per plant $(\mathrm{rp}=0.28)$ and seeds per pod $(\mathrm{rp}=0.15)$. This revealed that, improvement in any one or all of these positively related traits had contributed to selection of these characters for seed yield improvement.

The present finding was in line with [10] who observed highly significant positive phenotypic correlation of days to maturity, plant height and pods per plant with seed yield. This author also reported highly significant negative phenotypic correlation of seeds per pod with seed yield in contrast to this result. [11] Indicated the same results with the present findings. [4] Have reported highly significant positive phenotypic correlation of number of seeds per pod and significant positive phenotypic correlation of number of pods per plant and plant height with seed yield per plant. Similar result was also reported by [13] where; significant positive phenotypic correlation of number of pods per plant with seed yield per plant was observed. In contrast to this, this author reported negative significant phenotypic correlation of days to maturity and positive non-significant phenotypic correlation of number of seeds per pod and plant height with seed yield.

[19] Also reported positive significant correlation of days to maturity with grain yield. In contrary to the present findings, he reported negative significant correlation of number of seeds per pod with grain yield.

Stand count at harvest, 1000 seed weight, Ascochyta blight and powdery mildew disease exhibited non-significant positive phenotypic correlation with grain yield. Days to flowering showed non-significant negative phenotypic correlation with grain yield.

Days to flowering observed significant and positive phenotypic correlation with days to maturity. It implies that plants with early flowering may mature earlier. Days to maturity and plant height exhibited significant and positive correlation with number of pods per plant. It indicates that tall plants may produce more number of pods per plant. Days to flowering, maturity and plant height demonstrated significant and positive phenotypic correlation with number of seeds per pod. It indicates that tall plants supporting many leaves could increase total biomass production through increased carbon fixation that can be ultimately partitioned to reproduction organs and there by produce more number of pods and seeds and increase seed yield in field pea, which have positive and significant correlation with crop production. Similar results were reported by [11]. Days to flowering, maturity, plant height, number of seeds per pod, Ascochyta blight and powdery mildew indicated significant negative phenotypic correlation with thousand seed weight. Ascochyta blight showed significant positive phenotypic association with powdery mildew. Stand count, days to flowering, maturity and plant height exhibited significant negative phenotypic association with Ascochyta blight and powdery mildew disease.

Table 2. Genotypic ( $r g$ ) (above the diagonal) and phenotypic ( $r p$ ) (below the diagonal) correlation among different characters in 49 field pea genotypes tested combined over the two locations.

\begin{tabular}{|c|c|c|c|c|c|c|c|c|c|c|}
\hline Trait & SCAH & FD & MD & PH & PPP & SPP & TSW & GYKGH & AB & PM \\
\hline SCAH & 1.00 & $-0.19^{\text {ns }}$ & $0.05^{\mathrm{ns}}$ & $0.56^{* *}$ & $0.08^{\mathrm{ns}}$ & $-0.08^{\mathrm{ns}}$ & $0.44^{* *}$ & $0.15^{\mathrm{ns}}$ & $0.28^{*}$ & $0.02^{\mathrm{ns}}$ \\
\hline FD & $-0.20^{* *}$ & 1.00 & $0.35^{*}$ & $-0.03^{\text {ns }}$ & $0.15^{\mathrm{ns}}$ & $0.24^{\mathrm{ns}}$ & $-0.09^{\text {ns }}$ & $-0.13^{\text {ns }}$ & $-0.03^{\mathrm{ns}}$ & $0.04^{\mathrm{ns}}$ \\
\hline MD & $-0.34^{* *}$ & $0.26^{* *}$ & 1.00 & $0.45^{* *}$ & $0.31^{*}$ & $0.46^{* *}$ & $-0.22^{\mathrm{ns}}$ & $0.41^{* *}$ & $-0.24^{\mathrm{ns}}$ & $0.36^{*}$ \\
\hline PH & $-0.01^{\mathrm{ns}}$ & $0.11^{\mathrm{ns}}$ & $0.72^{* *}$ & 1.00 & $0.24^{\mathrm{ns}}$ & $0.24^{*}$ & $0.21^{\mathrm{ns}}$ & $0.67^{* *}$ & $0.22^{\mathrm{ns}}$ & $0.06^{\mathrm{ns}}$ \\
\hline PPP & $0.01^{\mathrm{ns}}$ & $0.09^{\text {ns }}$ & $0.13^{*}$ & $0.19^{* *}$ & 1.00 & $0.23^{\mathrm{ns}}$ & $-0.11^{\mathrm{ns}}$ & $0.33^{*}$ & $0.01^{\mathrm{ns}}$ & $0.00^{\mathrm{ns}}$ \\
\hline SPP & $-0.09^{\mathrm{ns}}$ & $0.18^{*}$ & $0.25^{* *}$ & $0.23^{* *}$ & $0.04^{\mathrm{ns}}$ & 1.00 & $0.04^{\mathrm{ns}}$ & $0.45^{* *}$ & $-0.17^{\mathrm{ns}}$ & $-0.08^{\mathrm{ns}}$ \\
\hline TSW & $0.46 * *$ & $-0.21^{* *}$ & $-0.73^{* *}$ & $-0.40^{* *}$ & $-0.06^{\mathrm{ns}}$ & $-0.16^{*}$ & 1.00 & $0.26^{\mathrm{ns}}$ & $0.25^{\mathrm{ns}}$ & $-0.28^{*}$ \\
\hline GYKGH & $0.08^{\mathrm{ns}}$ & $-0.05^{\mathrm{ns}}$ & $0.33^{* *}$ & $0.57^{* *}$ & $0.28^{*}$ & $0.15^{*}$ & $0.11^{\mathrm{ns}}$ & 1.00 & $-0.04^{\mathrm{ns}}$ & $0.06^{\mathrm{ns}}$ \\
\hline $\mathrm{AB}$ & $-0.24^{* *}$ & $0.18^{* *}$ & $0.76^{* *}$ & $0.59^{* *}$ & $0.04^{\mathrm{ns}}$ & $0.12^{\mathrm{ns}}$ & $-0.54^{* *}$ & $0.03^{\mathrm{ns}}$ & 1.00 & $0.01^{\mathrm{ns}}$ \\
\hline PM & $-0.35^{* *}$ & $0.20^{* *}$ & $0.92^{* *}$ & $0.63 * *$ & $0.05^{\mathrm{ns}}$ & $0.21^{* *}$ & $-0.70^{* *}$ & $0.07^{\mathrm{ns}}$ & $0.75^{* *}$ & 1.00 \\
\hline
\end{tabular}

Where: $-* *, *$, and $\mathrm{ns}=$ highly significant, significant and non-significant at $1 \%, 5 \%$ and $\mathrm{P}>0.05$ respectively. $\mathrm{SCAH}=\mathrm{Stand}$ count at harvest $(\%)$, DF $=\mathrm{Days}$ to $50 \%$ flowering (days), DM=Days to maturity (days), $\mathrm{PH}=$ Plant heigh (cm), $\mathrm{PPP}=\mathrm{Pods}$ per plant (number), $\mathrm{SPP}=\mathrm{Seeds}$ per pod (number), TSW=Thousand seed weight (grm, ), GYKGH=Grain yield (Kg/ha), AB=Ascochyta blight (1-9 scale), PM=Powdery mildew (1-9 scale).

Direct and indirect effect of different characters on grain yield of field pea genotypes at genotypic level is presented in Table 3.

Plant height exhibited the first maximum positive direct effect on grain yield at genotypic level which led to positive and significant correlation of this trait with grain yield. This finding was in conformity with that of [4].

The second higher positive direct effect was observed by 
number of pods per plant and number of seeds per pod on grain yield at genotypic level which led to positive and significant correlation of this trait with grain yield. [3] reported maximum direct effect of pods per plant and seeds per pod on yield, supported this findings.

Low positive direct effect was exhibited by days to mature and contributed indirectly to grain yield via plant height, seeds per pod, and pods per plant, powdery mildew and Ascocyta blight for its significant positive correlation with grain yield.

Stand count, thousand seed weight and powdery mildew also showed higher positive direct effect on grain yield which contributed for its non-significant positive correlation with grain yield.

Days to flowering showed the highest negative direct effect on grain yield which contributed for its non-significant negative correlation with grain yield.

The maximum positive indirect effect on grain yield was exhibited by stand count and days to maturity through plant height while the next maximum positive indirect effects were exerted by pods per plant and seeds per pod through plant height. That means, these traits influenced grain yield via their positive indirect effects on plant height.

The maximum negative indirect effect on grain yield was demonstrated by plant height through stand count while thousand seed weight and Ascochyta blight exerted maximum negative indirect effects through stand count. That means, that these traits influenced grain yield via their negative indirect effects on stand count.

The magnitude of residual effect (0.49) implied that traits included in path analysis described about $51 \%$ of the variation in grain yield at genotypic level. However, the remaining variation in grain yield (49\%) can be attained by incorporating other yield related components in the path analysis.

Table 3. Direct (bold face) and indirect effect (off diagonal) at genotypic level of nine traits on grain yield of 49 field pea genotypes at combined locations, Bekoje and Kofele.

\begin{tabular}{|c|c|c|c|c|c|c|c|c|c|c|}
\hline Traits & SCAH & FD & MD & PH & PPP & SPP & TSW & $\mathbf{A B}$ & PM & $\mathbf{r}_{\mathrm{ge}}$ \\
\hline SCAH & 0.443781 & 0.048872 & 0.000698 & 0.417945 & 0.0171 & -0.01714 & 0.163742 & -0.04048 & 0.003043 & 0.15 \\
\hline FD & 0.084318 & -0.25722 & 0.004886 & -0.02239 & 0.032062 & 0.051417 & -0.03349 & 0.004337 & 0.006086 & -0.13 \\
\hline MD & -0.02219 & -0.09003 & 0.01396 & 0.335849 & 0.066261 & 0.098549 & -0.08187 & 0.034698 & 0.054772 & $0.41 * *$ \\
\hline PH & -0.24852 & 0.007717 & 0.006282 & 0.746331 & 0.051299 & 0.051417 & 0.07815 & -0.03181 & 0.009129 & $0.67 * *$ \\
\hline PPP & -0.0355 & -0.03858 & 0.004328 & 0.179119 & 0.213746 & 0.049275 & -0.04094 & -0.00145 & 0 & $0.33^{*}$ \\
\hline SPP & 0.035502 & -0.06173 & 0.006421 & 0.179119 & 0.049162 & 0.214237 & 0.014886 & 0.024578 & -0.01217 & $0.45^{* *}$ \\
\hline TSW & -0.19526 & 0.02315 & -0.00307 & 0.15673 & -0.02351 & 0.00857 & 0.372141 & -0.03614 & -0.0426 & 0.26 \\
\hline $\mathrm{AB}$ & -0.12426 & 0.007717 & -0.00335 & 0.164193 & 0.002138 & -0.03642 & 0.093035 & -0.14458 & 0.001521 & -0.04 \\
\hline PM & -0.00888 & -0.01029 & 0.005026 & 0.04478 & 0 & -0.01714 & -0.1042 & -0.00145 & 0.152144 & 0.06 \\
\hline
\end{tabular}

Residual $=0.49 \mathrm{R}^{2}=0.75$ Where: $-* *, *$, and $\mathrm{ns}=$ highly significant, significant and non-significant at $1 \%, 5 \%$ and $\mathrm{P}>0.05$ respectively.. SCAH=Stand count at harvest $(\%), \mathrm{DF}=$ Days to $50 \%$ flowering (days), $\mathrm{DM}=$ Days to maturity (days), $\mathrm{PH}=\mathrm{Plant}$ heigh $(\mathrm{cm}), \mathrm{PPP}=\mathrm{Pods}$ per plant (number), $\mathrm{SPP}=\mathrm{Seeds}$ per pod (number), TSW=Thousand seed weight (grm,), GYKGH=Grain yield (Kg/ha), AB=Ascochyta blight (1-9 scale), PM=Powdery mildew (1-9 scale).

Direct and indirect effect of different characters on grain yield of field pea genotypes at phenotypic level is presented in Table 4.

Days to maturity demonstrated the highest positive direct effect on grain yield at phenotypic level which led to positive and significant correlation of this trait with grain yield. Similar result was reported by [10] who observed highest positive direct effect of days to maturity on grain yield. The second maximum positive direct effect was exerted by plant height relatively on grain yield and contributed indirectly to the grain yield via days to mature. It leads to positive and significant correlation of this this trait with grain yield. Low positive direct effect was exhibited by number of pods per plant and contributed indirectly to the grain yield via days to maturity and plant height for its significant positive correlation with grain yield. In contrasts to this finding, [1] reported high positive direct effect of pods per plant and seeds per pod on seed yield. 1000 seed weight and stand count exerted maximum positive direct effect on grain yield which contributed for its non-significant positive correlation with grain yield. Powdery mildew showed the highest negative direct effect on grain yield which contributed to its non-significant negative correlation with grain yield. The next maximum negative direct effect was exerted by Ascochyta blight and days to flower. Low negative direct effect was exhibited by seeds per pod on grain yield. This negative direct effect was counterbalanced by the positive indirect influence via days to mature and plant height for its significant positive correlation with grain yield.

The maximum positive indirect effect on grain yield was exhibited by powdery mildew, Ascochyta blight and plant height through days to maturity while the next maximum positive indirect effects were exerted by 1000 seed weight through powdery mildew and days to flower and number of seeds per pod through days to maturity.

The maximum negative indirect effects on grain yield was exhibited by 1000 seed weight through days to maturity while the next maximum negative indirect effects were exerted by Ascochyta blight and plant height through powdery mildew and stand count through days to maturity.

The magnitude of residual effect (0.34) indicated that traits included in path analysis explained about $66 \%$ of the variation in grain yield at phenotypic level. However, the remaining variation in grain yield (34\%) can be attained by incorporating other yield related traits in the phenotypic path analysis. 
Table 4. Estimates of direct (bold face) and indirect effect (off diagonal) at phenotypic level of nine traits on grain yield in 49 field pea genotypes of combined of the two locations, Bekoje and Kofele.

\begin{tabular}{lllllllllll}
\hline Traits & SCAH & FD & MD & PH & PPP & SPP & TSW & AB & PM & $\mathbf{r}_{\text {ph }}$ \\
\hline SCAH & 0.130143 & 0.033515 & -0.62131 & -0.00515 & 0.000749 & 0.00084 & 0.276329 & 0.106708 & 0.418459 & 0.08 \\
FD & 0.026029 & -0.16758 & 0.475117 & 0.056669 & 0.006743 & -0.00168 & -0.12615 & -0.08003 & -0.23912 & -0.05 \\
MD & 0.044249 & -0.04357 & 1.827372 & 0.370924 & 0.00974 & -0.00233 & -0.43852 & -0.33791 & -1.09995 & $0.33^{* *}$ \\
PH & 0.001301 & -0.01843 & 1.315708 & 0.515173 & 0.014235 & -0.00215 & -0.24029 & -0.26232 & -0.75323 & $0.57^{* *}$ \\
PPP & -0.0013 & -0.01508 & 0.237558 & 0.097883 & 0.074923 & -0.00037 & -0.03604 & -0.01779 & -0.05978 & $0.28^{*}$ \\
SPP & 0.011713 & -0.03016 & 0.456843 & 0.11849 & 0.002997 & -0.00934 & -0.09611 & -0.05335 & -0.25108 & $0.15^{*}$ \\
TSW & -0.05987 & 0.035191 & -1.33398 & -0.20607 & -0.0045 & 0.001494 & 0.600715 & 0.240093 & 0.836919 & 0.11 \\
AB & 0.031234 & -0.03016 & 1.388803 & 0.303952 & 0.002997 & -0.00112 & -0.32439 & -0.44462 & -0.8967 & 0.03 \\
PM & 0.04555 & -0.03352 & 1.681182 & 0.324559 & 0.003746 & -0.00196 & -0.4205 & -0.33346 & -1.1956 & 0.07 \\
\hline
\end{tabular}

Residual $=0.34, \mathrm{R}^{2}=0.88$ Where: - **, *, and ns=highly significant, significant and non-significant at $1 \%, 5 \%$ and $\mathrm{P}>0.05$ respectively. SCAH=Stand count at harvest, $\mathrm{DF}=$ Days to $50 \%$ flowering, $\mathrm{DM}=$ Days to maturity (days), $\mathrm{PH}=\mathrm{Plant}$ height $(\mathrm{cm}), \mathrm{PPP}=\mathrm{Pods}$ per plant, $\mathrm{SPP}=\mathrm{Seeds}$ per pod, $\mathrm{TSW}=\mathrm{Thousand}$ seed weight, $\mathrm{AB}=$ Ascochyta blight, $\mathrm{PM}=$ Powdery mildew.

\section{Conclusion}

The current study showed that plant height, days to maturity, pods per plant and seeds per pod exhibited highly significant genotypic and phenotypic correlation with grain yield for combined analysis. The association among most of traits demonstrated higher genotypic correlations than corresponding phenotypic correlations that; indicated the prevalence of genetic variation in expression of the traits. In some cases, however, the magnitudes of phenotypic correlation coefficients were higher than their corresponding genotypic correlation coefficients suggesting the importance of environmental effects. Genotypic path analysis indicated that plant height exerted the higher positive direct effect on grain yield followed by pods per plant, seeds per pod and days to maturity. Phenotypic path analysis also showed that days to maturity exerted maximum positive direct effect on grain yield followed by plant height and pods per plant. Therefore; selection for traits such as plant height, pods per plant, seeds per pod and days to maturity could improve grain yield in field pea.

\section{Conflict of Interests}

The authors have not declared any conflict of interests.

\section{References}

[1] Akanksha S, Aarti S, Tejasvi S, Rajesh K (2018). Correlation Coefficient and Path Coefficient analysis in Field pea (Pisum sativum L.). Internaational. Journal of Current. Microbiology and Applied Science 7 (2): 549-55.

[2] Aysh FM (2013). Inheritance and association of quantitative characteristics in Syrian landraces of garden peas (Pisum sativum L.). An International Journal of Life Sciences 2 (3): 198-203.

[3] Aziz-ur-R, Viveka K, Shweta S (2019). Studies on variability, correlation and path analysis in garden pea (Pisum sativum L.) for pod yield and its related traits under natural farming conditions. Journal of Pharmacology and Photochemistry SP1: 435-438.

[4] Benti O, Yohannis P (2017). Genetic variability and association among agronomic characters in selected field pea (Pisum sativum L.) genotypes at Bale Zone, Sinana Research Center, Oromia. International Journal of Genetics and Genomics, 5 (6): 63-75

[5] Bizeti HS, Carvalho CGP, Souza JRP, Destro D (2004). Path analysis under multicollinearity in soybean. Agronomy Journal 47: 669-676.

[6] CSA (Central Statistical Authority). 2018. Agricultural sample survey 2009/10. Report on area and production of major crops private peasant holdings, Meher Season. Addis Ababa. Statistical Bulletin no. 586. Volume 1.

[7] Dewey DR, Lu H (1959). A correlation and path coefficient analysis of components of crested wheat grass seed production. Agronomy Journal 51: 515-518.

[8] FAOSTAT (2017). Food and Agriculture Organization of the United Nations. Available online at http://www.fao.org/faostat/en/\#data/QC/visualize.

[9] Gregory E, Shana F, Hans K, Julie P, Michael W, Janet K, Kenneth H (2016). Field pea production, A1166, North Dakota State University Extension Service. p 3.

[10] Legesse D (2015). Genetic Variability and Association of Characters for Yield and Yield Components in Some Field Pea (Pisum Sativum L.) Genotypes Grown in the Central Highlands of Ethiopia. An M Sc. Thesis presented to the School of Graduates Studies of Haramaya University, Haramaya, Ethiopia.

[11] Million F (2012). Variablity, Heriatablity and Associattion of Some Morpho-Agronomic Traits in Field Pea (Pisium Sativum L.) Genotypes. Pakistan Journal of Bilogical Science 15 (80): 358-366.

[12] Parveen SI, Sekhar MR, Reddy DM, Sudhakar P (2011). Correlation and path coefficient analysis for yield and yield components in blackgram (Vigna mungo L. Hepper). International Journal of Applied Biology and Pharmacology Technology. 2: 619-625.

[13] Rafiul A, Firoz M, Mir AR (2017). Genetic diversity, correlation and path analysis for yield and yield components of pea (Pisum sativum L.). World Journal of Agricultural Sciences 13 (1): 11-16.

[14] Robinson HF, Comstock RE, Harvey VH (1951). Genotypic and phenotypic correlation in corn and their implications in selection. Agronomy Journal 43: 280-281. 
[15] SAS (2002). System Analysis Software vertion 9.0. SAS Institute Inc., Cary, North Carolina, USA.

[16] Sahile S, Ahmed S, Fininsa C, Abang M, Sakhuja PK (2008). Survey of chocolate spot (Botrytis fabae) disease of faba bean (Vicia faba L.) and assessment of factors influencing disease epidemics in northern Ethiopia. Crop Protection 27: 14571463.

[17] Singh RK, Chaudhary BD (1985). Biometrical Methods in Quantitative Genetic Analysis, Kalyani Publishers, New Delhi, PP. 318.

[18] Singh T, Sharma A, Alie FA (2009). Morpho-physiological traits as selection criteria for yield improvement in mungbean
(Vigna radiata L. Wilczek). Legume Research International Journal 32: 36-40.

[19] Tamene TT (2017). Genetic Variation, Heritability, And Advances From Selection In Elite Breeding Materials Of Field Pea (Pisum Sativum L.). Agrecultural Research and $\begin{array}{lllll}\text { Technology } & 8 & (4): & 555740 . & \text { DOI: }\end{array}$ 10.19080/ARTOAJ.2017.08.555744.

[20] Teshome E, Tegegn A (2017). Comparative Study of Powdery Mildew (Erysiphe polygoni) Disease Severity and Its Effect on Yield and Yield Components of Field Pea (Pisum sativum L.) in the Southeastern Oromia, Ethiopia. Journal of Plant Pathol ogy and Microbiology 8: 410. doi: 10.4172/21577471.1000410 . 